\title{
Development Analysis of Global Competitiveness Index of ASEAN-7 Countries and Its Relationship on Gross Domestic Product
}

\author{
Tongam Sihol Nababan \\ Nommensen HKBP University, Medan, Indonesia \\ tsnababan@gmail.com
}

\begin{abstract}
The objectives of the research are: (1) to investigate the development of global competitiveness index (GCI) of ASEAN-7 countries as an illustration of economic performance and potentiality, (2) to investigate which factors or pillars are drivers for the improvement of GCI ASEAN-7 countries, and (3) to analyze the effect of Gross Domestic Product (GDP) on GCI of ASEAN-7 countries. The analysis method used in calculating the weight of the contribution of each pillar to changes in the competitiveness index, and determining the effect of GDP on GCI, a SemiLogarithmic Regression analysis is used. The result shows that during the period of year 2008/2009 to the year of 2016/2017, the rank and index of GCI of each ASEAN-7 countries continue to increase. The pillars of the basic requirement subindex still dominate the largest contribution to the improvement of the competitiveness index for Indonesia, Philippines, Thailand, Cambodia, and Vietnam. As for Malaysia and Singapore sub-indexes of efficiency enhancers and innovation-sophistication have been able to give the largest contribution to the improvement of GCI. The GDP of ASEAN-7 countries has a positive and significant impact on the improvement of global competitiveness index, except for Thailand. The most problematic factors in improving the competitiveness index are corruption, inadequately educated labour, access to financing, tax regulations, and inefficient government bureaucracy.
\end{abstract}

Article Info

- Received : October 19, 2018

- Revised : December 14, 2018

- Published : January 05, 2019

- No. Pages : $1-14$

- DOI : 10.33019/ijbe.v3i1.108

- JEL : F63, O57

- Keywords : GCI, GDP, basic requirement, efficiency enhancers, innovation-sophistication

\section{Introduction}

Ranking of competitiveness, the prospect of economic growth and their forming factors have been on the agenda in almost more than 25 years. Certainly, this is done related to the process of economic internationalization that occurs in the world today. According to Hutabarat (2014), the economic consultancy institutions and the company executives are competing to use it to analyze and devise suggestions and implement policies needed to improve a country's performance indicators and competitiveness rating. 
One of the raters that widely known by the business executives and the policymakers is the World Economic Forum (WEF) with the Global Competitiveness Index (GCI). The impact of a policy based on this index is very influential (Xia et al., 2012). For example, GCI ranks some countries based on their competitive ability. If a country is classified as a country with a low GCI, the businessmen believe that this country will not be able to develop according to its capabilities, and vice versa.

Since 2004, the WEF has compiled a GCI as a report on the competitiveness ranking of countries in the world, including ASEAN countries. Starting since 2007, one of the objectives of the ASEAN Economic Community (AEC) is to improve the competitiveness and ASEAN has implemented many activities that can encourage improvement of its competitiveness. The main issue of ASEAN is that the concept of competitiveness is increasingly emphasized on the ability of ASEAN countries to follow the flow of liberalization and trade with free of barriers, in which tends to limit the role of the government. This situation brings pressure on competition against the domestic market of ASEAN countries and around the world.

Based on the WEF Report year of 2014 - 2015 which released the GCI of 2014-2015, of the 9 (nine) members of the AEC (outside of Brunei Darussalam), Singapore has the highest competitiveness rating, the 2 nd rank out of 144 countries in the world. Malaysia ranked 20th and Thailand ranked 31th, while Indonesia ranked 34th. Indonesia's competitiveness ranking has increased by for 4 points compared to Indonesia's competitiveness in the year of 2013-2014 which was ranked 38th. Meanwhile, in the previous 2 years, Indonesia was still ranked 50th in the world.

The GCI is built from 112 different components and grouped into 12 competitiveness pillars, and pillars are classified into three components, namely: "factors" which determine a better environment for high productivity (Bai, 2009), "efficiency " which is connected to labor, market goods and services and their effects on production efficiency (Qin et al., 2009), and " innovation", which is needed for the growth of sustainability (Koong et al., 2011).

This research is carried out on ASEAN countries that have formed the axis of the AEC. This community is oriented towards enhancing the ASEAN's ability to follow the flow of barrier-free liberalization and trade, strengthening the rules and regulations of the international trade system. Therefore the competitiveness index of ASEAN countries is important to be examined. By knowing the global competitiveness index, it can be known as the performance, the productivity, and the economic potentiality of ASEAN countries. This research will discuss the development of the competitiveness index ranking, observing the GCI driving factors of ASEAN countries and their relationship to Gross Domestic Product (GDP). Factors that hinder the increase in GCI are also discussed. Due to the limitation of data in several countries, the study is only conducted in ASEAN-7 countries, namely the Philippine, Cambodia, Malaysia, Indonesia, Singapore, Thailand, and Vietnam.

\section{Literature Reviews}

\section{Global Competitiveness Index and Economic Growth}

The Organization for Economic Cooperation and Development (OECD) Program on Technology and the Economy 1992 defines that a country's competitiveness is based on better productivity 
performance and the ability of the economy to increase output to a higher level of activity which in turn can generate a high level of real wages. Competitiveness is related to an increasing standard of living, developing employment opportunities, and the ability of a nation to maintain its international obligations. Competitiveness can be limited as an open market environment, which can produce goods and services that pass the competitiveness test and at the same time maintain and expand domestic real income (Monga \& Lin, 2015).

The WEF (1996) defines that a country's competitiveness is as a national economic ability to achieve sustainable growth rates as measured by annual changes in GDP per capita (IDABC Government Observatory, 2005). A country is said to be competitive if its population can enjoy a high standard of living and increase and its employment opportunities are always high continuously. The WEF publishes the GCI Report every year with the aim of assessing the capacity of the world economy to achieve sustainable economic growth (McArthur \& Sachs, 2002). One important component of the GCI Report is to summarize a nation's technological strengths, features of public institutions and the macroeconomic environment. This index underwent a major revision in 2005 due to the inability to capture the effects of globalization.

Based on data survey, the 2007-2008 GCI Report covers nine important pillars to improve the competitiveness of a nation and its economic growth, namely: institutions, infrastructure, macroeconomy, health and primary education, higher education and training, market efficiency, technological readiness and business sophistication, and innovation, (Lopez-Claros et al., 2007). Then the 2010-2011 CGI Report develops the market efficiency of goods, labor, financial markets, and market size, so that it contains 12 pillars, as shown in Figure 1.

However, the two GCI Reports (the year of 2007-2008 and 2010-2011) classify all pillars into three economic components: factors, efficiency, and innovation. Economic factors refer to macro-level institutions and infrastructure that create a better environment for high productivity (Bai, 2009). Economic efficiency consists of labor, goods, services and other markets needed for efficient production (Qin et al., 2009). Finally, economic innovation refers to if a country is proinnovation, which indicates that growth can be sustained (Koong et al., 2011).

Due to the GCI measures the productivity of a country, it is often interpreted that a country's economic growth can not only be made but also must be sustainable which can be demonstrated by a high index. Therefore, the GCI contains the short-term components and the long-term components that can explain the economic growth potentiality. As claimed by the authors of this index, the GCI can determine the aggregate growth of the economic level (Lopez-Claros et al., 2007). Kordalska \& Olczyk (2016) and Martin (2004) state, in fact, most of these pillars are taken from six major economic theories: classical, neoclassical and Keynesian economic theory, development economics, trade theory, and economic growth theory. Therefore, the determinants of economic growth often become "key drivers" simultaneously in the GCI pillars, so it can be said that the GDP growth rate can predict the Global Competitiveness Index (GCI) (Figure 1). Vice versa that the GCI can be a good predictor of the GDP growth (Rota, 2013). This statement has been reinforced by Lopez-Claros et al. (2007) which state that GCI can determine the aggregate level of economic growth. Schwab (2015) also argues that a more competitive economy will grow faster over time. 


\section{Gross Domestic Product (GDP)}

To measure economic growth economists use Gross Domestic Product (GDP) data that measures the income of everyone in the economy. GDP is the broadest measure of overall economic conditions because it can measure income and total expenditure on the economy (Mankiw, 2007). In developing countries, which are often used as "Third World" the concept of GDP is the most important concept compared to other national income. Gross Domestic Product can be interpreted as the value of goods and services produced in that country in a given year, namely the value of goods and services in a country produced by factors of production belonging to the citizens of those countries and foreign countries (Sukirno, 2010).

According to Bank Indonesia (2016), Gross Domestic Product (GDP) is an important indicator to determine the economic development in a country in a period certain, both at current prices and at constant prices. GDP is basically the amount of added value generated by all business units in a particular country in a certain period. The total value of the final goods and services provided by the production must be the same as the value of the goods used. GDP at current prices illustrates the added value of goods and services calculated using the prevailing prices every year, while GDP at constant prices shows the added value of goods and services which are calculated using prices prevailing in a given year as the base year. GDP according to current prices is used to determine the shift and economic structure of a country. Meanwhile, constant GDP is used to determine the ability of resources to drive economic growth in real terms from year to year or economic growth that is not influenced by price factors. GDP can also be used to determine price changes by calculating the GDP deflator (change in the implicit index). The implicit price index is the ratio between GDP according to current prices and GDP according to constant prices. The conceptual calculation of Gross Domestic Product uses three types of approaches, namely: production approach, expenditure approach and income approach.

\section{Components of the Global Competitiveness Index and Weight}

In the WEF Report year of 2016-2017, the GCI components are divided into 3 sub-indices (Figure 1) namely basic requirements, efficiency enhancers, and innovation and sophistication factors. Basic requirements are the basic factors that must be possessed to produce high productivity. Efficiency enhancers are factors that influence to create production efficiency.

While Innovation and sophistication factors are the factors needed for sustainable growth. Raimanu (2016) expresses that these three sub-indices are the economic stages of a country, namely: in the early stages of the economy are more driven by natural factors (such as natural resources and unskilled labor), then at a later stage by efficiency factors, and at the last stage by the innovation factor. Meanwhile, according to Tambunan (2011) and Nababan (2014), these three factors can determine the level or competitiveness index of a country. The three subindexes have 12 pillars with 112 variables. The 12 pillar structure and weight (\%) are as follows:

BASIC REQUIREMENTS $20-60 \%$

1st pillar: Institutions $.25 \%$

2nd pillar: Infrastructure .............................25\%

3rd pillar: Macroeconomic environment.........25\%

4th pillar: Health and primary education ........25\% 
EFFICIENCY ENHANCERS. $35-50 \%$

5th pillar: Higher education and training ........17\%

6th pillar: Goods market efficiency ................17\%

7th pillar: Labor market efficiency ................17\%

8th pillar: Financial market development ......17\%

9th pillar: Technological readiness ................17\%

10th pillar: Market size .................................17\%

INNOVATION AND SOPHISTICATION FACTORS

11th pillar: Business sophistication.

12th pillar: R\&D Innovation. $.50 \%$

Basic Requirements Sub-index

Efficiency Enhancers Sub-index
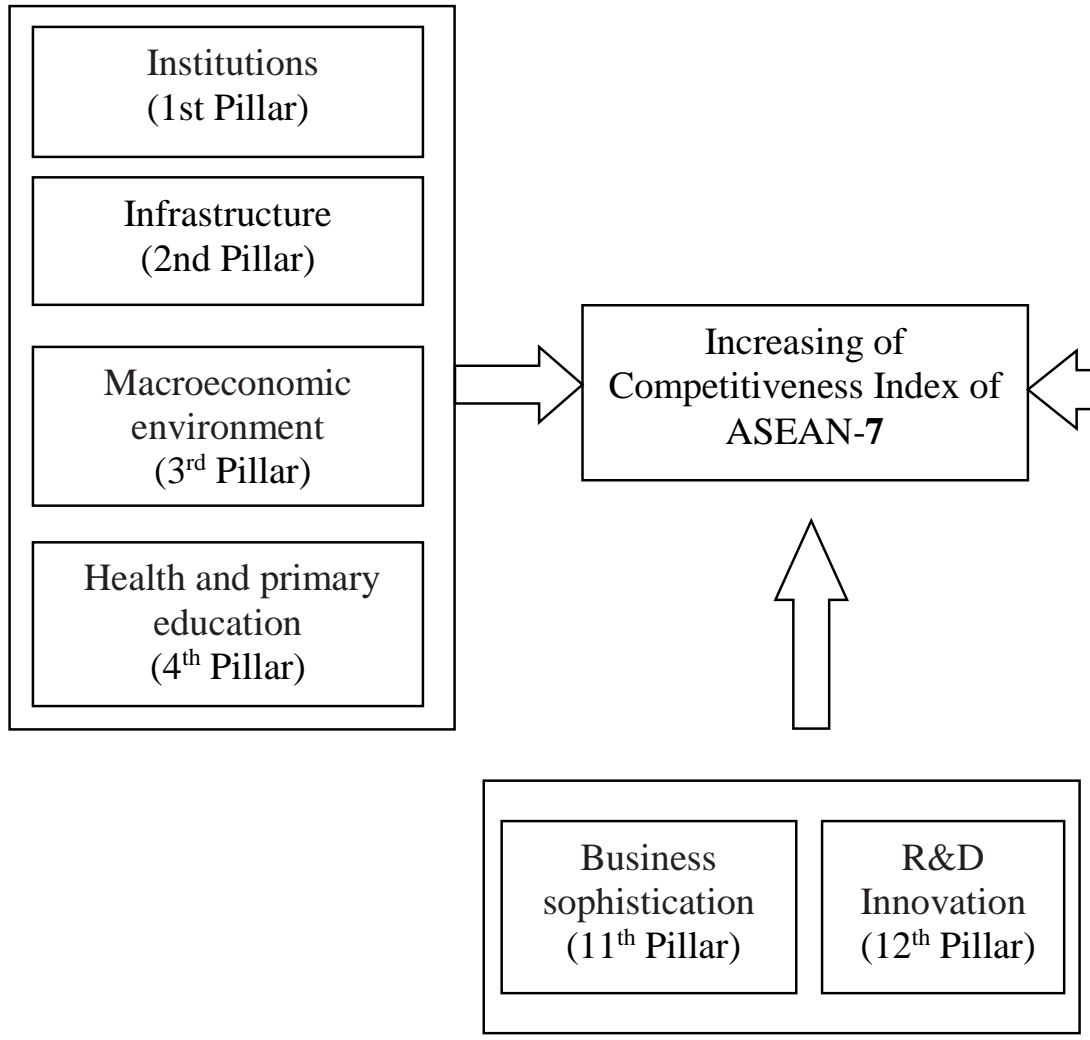

Higher education and training ( $5^{\text {th }}$ Pillar $)$

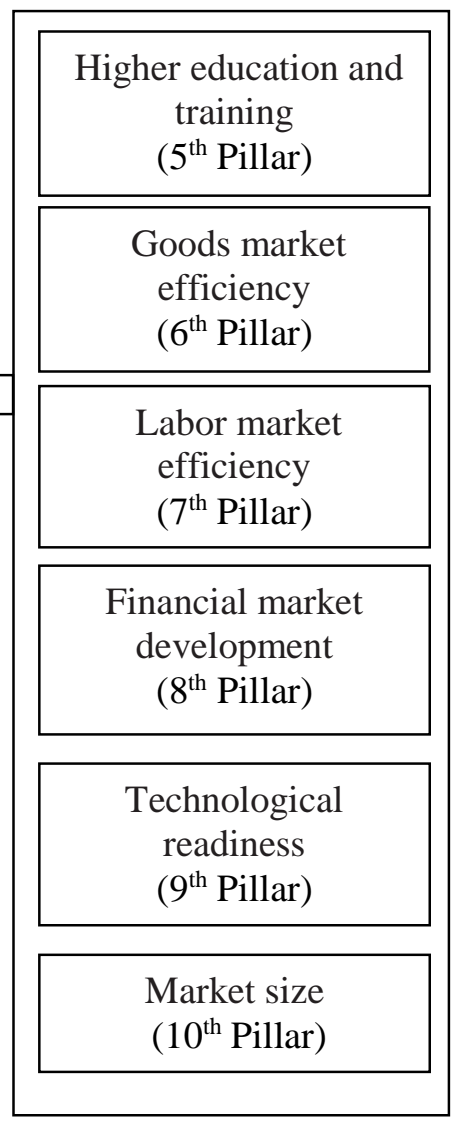

Innovation and Sophistication

Factors Sub-index

\section{Figure 1. Driver Factors of Competitiveness}

\section{Research Methods}

\section{Data and Variables}

The research data is secondary data in the form of Global Competitiveness Index (GCI) which is sourced from the WEF Report which contains a score of 1 to 7 and rankings from ASEAN-7 countries (Philippine, Cambodia, Malaysia, Indonesia, Singapore, Thailand, Vietnam) during the 
period 2008-2009 to 2016-2017. Research variables consist of GDP and GCI. The GCI consists of 3 sub-indices and 12 pillars (as shown in Figure 1).

\section{Analysis Method}

To analyzing drivers' pillars that contribute to changes in the competitiveness index of each ASEAN-7 country based on the weight (\%) of sub-indexes and the state revenue category for each stage of development (Table 1), the following steps are taken:

1. Determine the position of the stage of development of a country based on the category of GDP per capita.

2. Determine the weight (\%) of each sub-index for each stage of development.

3. Calculating the weight of each competitiveness pillar based on the weight of the sub-index and the weight of each pillar.

4. Calculating the value of changes in the competitiveness index for each pillar from the previous year to the following year.

5. Calculating the weight of the contribution of each pillar to changes in the competitiveness index.

Table 1. Weight (\%) of Sub-index and GDP Per Capita for Stage of Development

\begin{tabular}{|l|c|c|c|c|c|}
\hline \multirow{2}{*}{ Description } & \multicolumn{5}{c|}{ Stage of Development } \\
\cline { 2 - 6 } & $\begin{array}{c}\text { Stage 1: } \\
\text { Factor- } \\
\text { driven }\end{array}$ & $\begin{array}{c}\text { Transition } \\
\text { from stage } \\
1 \text { to stage 2 }\end{array}$ & $\begin{array}{c}\text { Stage 2: } \\
\text { Efficiency- } \\
\text { driven }\end{array}$ & $\begin{array}{c}\text { Transition } \\
\text { from stage } \\
\text { 2 to stage 3 }\end{array}$ & $\begin{array}{c}\text { Stage 3: } \\
\text { Innovation- } \\
\text { driven }\end{array}$ \\
\hline GDP per capita (US \$) & $<2,000$ & $\begin{array}{c}2,000- \\
2,999\end{array}$ & $\begin{array}{c}3,000- \\
8,999\end{array}$ & $\begin{array}{c}9,000- \\
17,000\end{array}$ & $>17,000$ \\
\hline Weight for basic requirements & $60 \%$ & $40-60 \%$ & $40 \%$ & $20-40 \%$ & $20 \%$ \\
\hline $\begin{array}{l}\text { Weight for efficiency } \\
\text { enhancers }\end{array}$ & $350 \%$ & $35-50 \%$ & $50 \%$ & $50 \%$ & $50 \%$ \\
\hline $\begin{array}{l}\text { Weight for innovation and } \\
\text { sophistication factors }\end{array}$ & $5 \%$ & $5-10 \%$ & $10 \%$ & $10-30 \%$ & $30 \%$ \\
\hline
\end{tabular}

Source: WEF Report (2016-2017)

To explaining the development of the GCI of ASEAN-7 countries, descriptive analysis was used, and to determine the effect of GDP on GCI, a Semi-Logarithmic Regression analysis with the following specifications is used:

$G C I_{i t}=\alpha+\beta L n G D P+e$

Where: $\alpha=$ constant; $\beta=$ regression coefficient; $i=$ ASEAN-7 countries; $t=$ time period of 20082009 to $2016-2017$.

\section{Results and Discussion}

\section{Development of Global Competitiveness Index (GCI) of ASEAN-7 Countries}

Figure 2 presents the ranking of ASEAN-7 GCI from 2008 to 2016. The graph shows that the Philippine, Vietnam, Indonesia, Malaysia, and Singapore experience an increase in competitiveness scores. In 2008-2009 the Philippine score was 4.09, in 2012-2013 with a score of 4.11 and in 2016-2017 with a score of 4.31. This increase had improved the position of the 
Philippine to the rank of 60th in the world in 2016-2017 from the 71st rank in 2008-2009. Vietnam has a score of 4.10 in 2008-2009, a score of 4.23 in 2012-2013, and 2016-2017 with a score of 4.36. This increase has raised Vietnam's world ranking significantly from position 71 to position of 65th and jumped to the position of 57th in 2016-2017.

Indonesia also experiences an increase in scores over the three years, each of $4.25 ; 4.40$ and 4.52. This score raised Indonesia's world ranking by 14 points in 2008-2009 to 41st in 2016-2017. Malaysia's competitiveness score also increases slightly over the three years, each of 5.04; 5.06 and 5.16 but its position drops from the rank of 21th to rank of 25 th. While Singapore is significantly able to increase its position from the rank of 5th in 2012-2013 to rank of 2nd in the world rankings in 2016-2017, this country has the highest score among ASEAN-7 with a score of 5.53; 5.67 and 5.72. Meanwhile, Thailand's position does not experience a significant increase, only rise by 4 points from the rank of 38th in 2012-2013 to rank of 34th in 2016-2017. The decreasing position is experienced by Cambodia with a score of 4.01 in 2012-2013 drops to score of 3.98 in 2016-2017. This has reduced Cambodia's world ranking from the rank of 85th to 89th.

For ASEAN-7, in 2016-2017 Singapore has the highest competitiveness index (rank of 2nd), followed by Malaysia (rank of 25th), Thailand (rank of 34th), Indonesia (rank of 41th), Vietnam (rank of 57th), Philippines (rank of 60th) and Cambodia (rank of 89th). In general, during the period of 2008-2008 to 2016-2017, ASEAN-7 countries' GCI ranks continue to increase. This is consistent with the study of Tan \& Tan's (2014) which states that during the year of 2000 to 2010 ASEAN countries have experienced an increase in competitiveness in the Asian region.

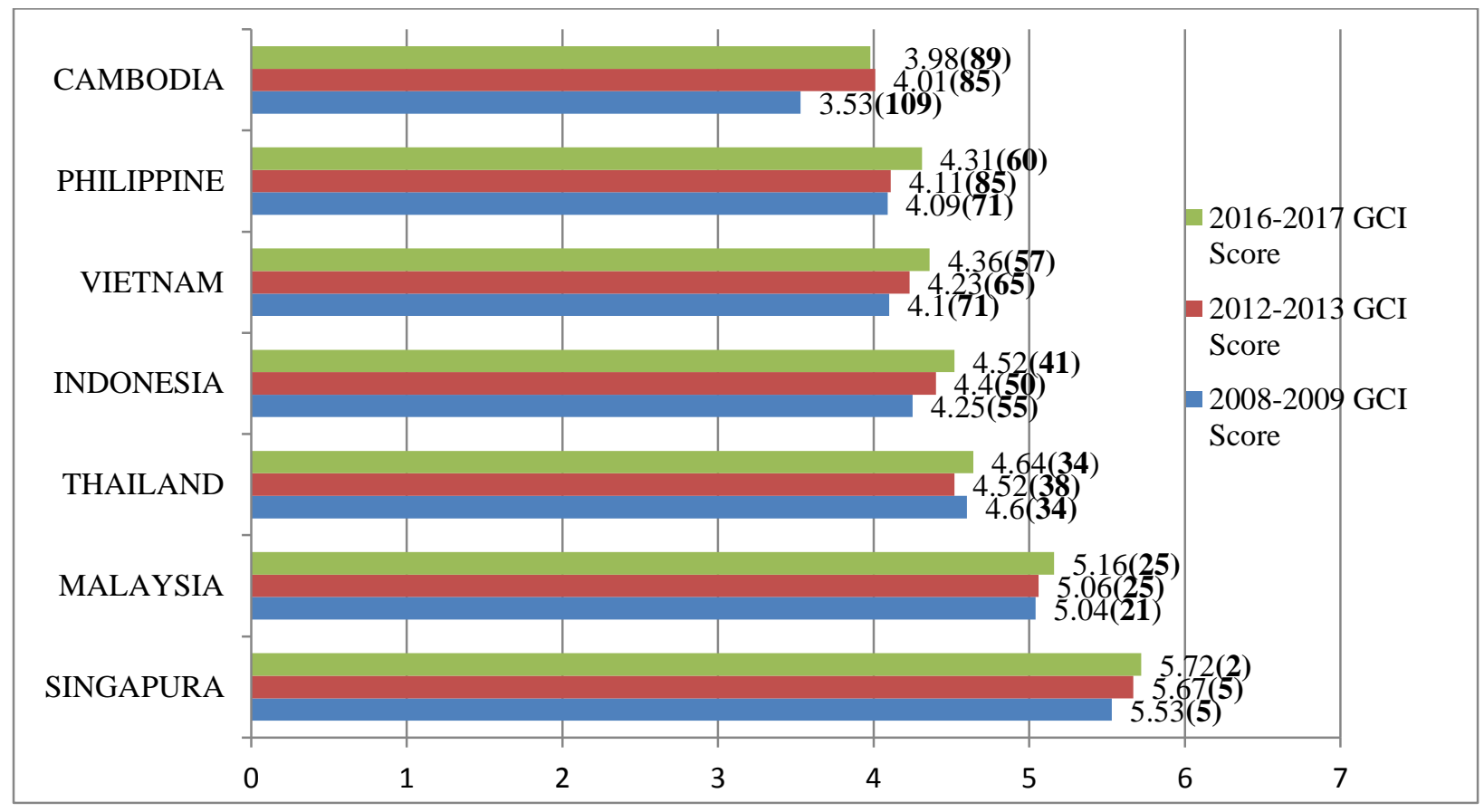

Figure 2. Competitiveness Index and World Ranking of ASEAN-7 


\section{Driving Factors of Competitiveness Index and the Influence of Gross Domestic Product on the Global Competitiveness Index}

Based on Table 1, the position of ASEAN-7 countries is at the following stages shown in Table 2. Then, Table 3 presents the regression summary of the influence of GDP on GCI of ASEAN-7.

Table 2. The position of Development Stages of ASEAN-7 Countries

\begin{tabular}{|c|c|c|c|}
\hline Country & $\begin{array}{c}\text { GDP Per Capita } \\
\text { (US \$) }\end{array}$ & $\begin{array}{c}\text { Stage of } \\
\text { Development }\end{array}$ & Description \\
\hline Philippine & $2,858.1$ & Transition 1 & Transition Stage 1 to Stage 2 \\
\hline Indonesia & $3,362.4$ & Stage 2 & Efficiency-driven \\
\hline Cambodia & 1,168 & Stage 1 & Factor-driven \\
\hline Malaysia & $9,556.8$ & Transition 2 & Transition Stage 2 to Stage 3 \\
\hline Singapore & $52,887.8$ & Stage 3 & Innovation-driven \\
\hline Thailand & $5,742.3$ & Stage 2 & Efficiency-driven \\
\hline Vietnam & $2,088.3$ & Transition 1 & Transition Stage 1 to Stage 2 \\
\hline
\end{tabular}

Source: WEF Report 2016-2017, data processed by author.

Table 3. Influence of GCI on GDP

\begin{tabular}{|c|c|c|c|}
\hline Country & LnGDPa) $^{\mathbf{a}}$ & $\mathbf{R}^{\mathbf{2}}$ & t-value \\
\hline ASEAN-7 & 0.519 & 0.269 & $4.737 * * *$ \\
\hline Philippine & 0.904 & 0.817 & $5.587 * * *$ \\
\hline Indonesia & 0.859 & 0.738 & $4.445^{* * *}$ \\
\hline Cambodia & 0.791 & 0.625 & $3.416^{* *}$ \\
\hline Malaysia & 0.740 & 0.548 & $2.915^{* *}$ \\
\hline Singapore & 0.892 & 0.795 & $5.215^{* * *}$ \\
\hline Thailand & 0.457 & 0.209 & 1.361 \\
\hline Vietnam & 0.647 & 0.418 & $2.244^{*}$ \\
\hline
\end{tabular}

Dependent Variable: GCI; ${ }^{\text {a) }}$ Standardized Coefficient

*** significant at level of $1 \%, * *$ significant at level of $5 \%$, *significant at level of $10 \%$.

Philippine. Philippine's GDP per capita (nominal) is the US \$2,858.10 and has a position in the transition stage 1 to stage 2 . The competitiveness index value increased by 0.22 point from 4.09 in 2008-2009 to 4.31 in 2016-2017. This increase is driven by the basic requirements sub-index, especially with the improvement in the macroeconomic variables pillar. Significantly, this pillar contributes $10.05 \%$ to increase the competitiveness. Then, followed by improvements in the infrastructure sector with a contribution of $7.65 \%$, the basic education and health sectors at $6.00 \%$. On the institutional pillar, there is only a slight improvement. The total value of GCI changes from 2008-2009 to 2016-2017 is 36.45\%. The Basic Requirements sub-index gives the contribution of $26.40 \%$, the contribution of the Efficiency Enhancers sub-index as of $8.90 \%$, and the contribution of the Innovation \& Business Sophistication sub-index is $1.15 \%$. Thus the Philippines must pay more attention to improving the efficiency of the goods market, the labour market, and business sophistication. Then, it is necessary to pay attention to improving financial markets. The strength of the Philippines is in the macroeconomic sector, infrastructure development, and basic education and health. Even at the ASEAN-7 level, especially the increase in the macroeconomic sector, the Philippine is higher than in other countries. This 
achievement is supported by the regression analysis between GCI and GDP of Philippine: $\boldsymbol{G C I}=$ 0.904LnGDP, as shown in Table 3. The GDP of Philippine has a positive and very significant effect $(\alpha=0.01)$ on GCI. An increase of $1 \%$ in the GDP of Philippine will be able to raise GCI by 0.904 points. It means that GDP is an excellent predictor of global competition.

Indonesia. Indonesia's GDP per capita (nominal) is the US \$ 3,362.40 and positioned in stage 2 (efficiency-driven). The value of the competitiveness index increased by 0.27 point from 4.25 in 2008-2009 to 4.52 in 2016-2017. The total value of GCI change from 2008-2009 to 2016-2017 is $27.44 \%$, where the Basic Requirements sub-index contributes as $21.20 \%$, the contribution of the Efficiency Enhancers sub-index is $4.49 \%$, and the contribution of the Innovation \& Business Sophistication sub-index is $1.75 \%$. The increase in Indonesia's competitiveness index is mostly contributed by the infrastructure sector, macroeconomic factors, basic education, and market expansion. The technology readiness factor also shows good improvement. Institutional and innovation factors also provide a positive increase.

Whereas the pillars of basic education and health are stagnant, although they show a little positive improvement. However, on the pillars of market and labour market efficiency, financial markets, and business sophistication show a decrease in contributions, especially the labour market sector. Indonesia's strength is currently in the development of the infrastructure sector, especially in the last 3 years after Joko Widodo becomes a president. Indonesia must pay more serious attention to labour market factors. According to the Central Statistics Agency (BPS), the open unemployment rate in February 2016 was still high at 7.02 million people or 5.5 percent. However, the number of unemployed people decreased when compared to February 2015, which reached 7.45 million people (5.81 per cent). The influence of GDP on GCI showed by the

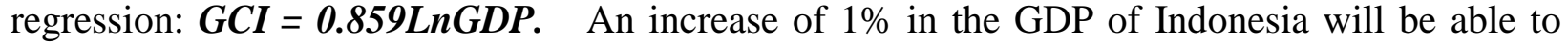
raise GCI by 0.859 points. GDP has a positive and very significant effect $(\alpha=0.01)$ on GCI. For Indonesia, GDP is a very good predictor to improve the global competition.

Cambodia. Cambodia's GDP per capita (nominal) is the US $\$ 1,168$ and positioned in stage 1 (factor driven). The value of the competitiveness index increased by 0.45 point from $2008-2009$ to 3.98 in 2016-2017. The total value of GCI change from 2008-2009 to 2016-2017 is $44.66 \%$, where the Basic Requirements sub-index contributes as $29.70 \%$, the contribution of the Efficiency Enhancers sub-index is $14.41 \%$, and the contribution of the Innovation \& Business Sophistication sub-index is $0.55 \%$. There are 11 pillars provide positive improvements to increase Cambodia's competitiveness index, while the labour market efficiency factor contributes negatively. The pillars of basic education, macroeconomics, infrastructure development, financial markets, and technological readiness contribute significantly to increase competitiveness. While the other pillars can be said to be relatively constant even though there is a slight positive impact. As a country positioned in stage 1, Cambodia has relatively succeeded in building its basic requirements in the past decade, especially in basic education and health and the macroeconomic environment as capital to produce high productivity. The GDP of Cambodia becomes a good predictor in improving the global competition. It has a positive and significant effect $(\alpha=0.05)$ on GCI, as shown by regression: $\boldsymbol{G C I}=0.791 \mathrm{LnGDP}$. By increasing $1 \%$ of GDP, the CGI will raise as 0.791 points. 
Malaysia. Malaysia's GDP per capita (nominal) is the US \$ 9,556.80, and it is in transition phase 2 (transition stage 2 to stage 3 ). The value of the competitiveness index increased by 0.12 points from 2008-2009 to 5.16 in 2016-2017. The total value of GCI change from 2008-2009 to 2016-2017 is $15.19 \%$, where the Basic Requirements sub-index contributes as $2.03 \%$, the contribution of the Efficiency Enhancers sub-index is $7.06 \%$, and the contribution of the Innovation \& Business Sophistication sub-index is $6.10 \%$. The pillars in the efficiency enhancer's sub-index except financial markets have contributed positively to the increase of Malaysia's competitiveness index. Malaysia's strength is in the pillar of innovation. This is supported by the technology readiness factor. Other pillars make a positive contribution, except for the financial market and labour market pillars are still weak while macroeconomic environmental factors remain constant. The regression result between GDP and GCI as presented

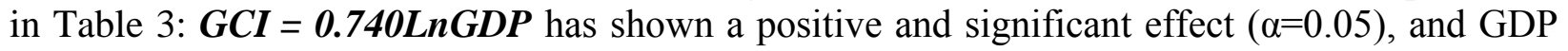
can be a predictor for GCI.

Singapore. Singapore's GDP per capita (nominal) income is the US $\$ 52,887.80$ and positioned in stage 3 (innovation driven). The value of the competitiveness index increased by 0.19 point from 5.53 in 2008-2009 to 5.72 in 2016-2017. The total value of GCI changes from 2008-2009 to $2016-2017$ is $18.45 \%$, where the Basic Requirements sub-index contribution is $4.70 \%$, the contribution of the Efficiency Enhancers sub-index is $11.05 \%$, and the Innovation \& Business Sophistication sub-index has contributed positively to the improvement of Singapore's competitiveness index.

As a country positioned in stage 3, Singapore has succeeded in placing itself as an innovation centre in the world. This performance has been supported by the strength of the factors of higher education and technological readiness. Other pillars are enough to make a positive contribution to improving the competitiveness index. But other factors such as institutions, goods markets, financial markets, and business sophistication do not have a positive impact. The performance of Singapore has been supported by the regression analysis between GCI and GDP: $\boldsymbol{G C I}=$ 0.892LnGDP. The GDP of Singapore has a positive and very significant effect $(\alpha=0.01)$ on GCI. An increase of $1 \%$ in the GDP of Singapore will be able to raise GCI by 0.892 points. It means that GDP is a very good predictor of global competition.

Thailand. Thailand's GDP per capita (nominal) is the US \$ 5,742.30 and positioned in stage 2 (efficiency-driven). The value of the competitiveness index increased by 0.04 points from 4.60 in 2008-2009 to 4.64 in 2016-2017. The total value of GCI's change from 2008-2009 to 2016-2017 is $3.91 \%$, with the contribution of the Efficiency Enhancers sub-index as 5.36\%. The contribution of the Basic Requirements sub-index and the Innovation \& Business Sophistication sub-index actually decreased by $0.90 \%$ and $0.55 \%$ respectively. Thailand's strength to improve its competitiveness index significantly lies in the pillars of macroeconomic environment and technology readiness. The pillars of market size, the efficiency of the goods market, higher education and innovation have contributed positively to the competitiveness index. But the other pillars do not have a positive impact. The low increase of GCI in Thailand is also indicated by the insignificance effect of GDP on GCI. The regression of $\boldsymbol{G C I}=\mathbf{0 . 4 5 7} \mathbf{L n G D P}$ has a positive effect but not significant. 
Vietnam. Vietnam's GDP per capita (nominal) income is the US \$2,088.3 and positioned in transition 1 (transition stage 1 to stage 2). The value of the competitiveness index increased by 0.25 point from 4.10 in $2008-2009$ to 4.36 in 2016-2017. The total value of GCI changes from 2008-2009 to 2016-2017 is 22.95\%, where the Basic Requirements sub-index contributes as $15.75 \%$, the contribution of the Efficiency Enhancers sub-index is $8.50 \%$, but the contribution of the Innovation \& Business Sophistication sub-index drops by $1.30 \%$. The infrastructure pillar greatly contributes to the improvement of Vietnam's competitiveness index, followed by the pillars of health and basic education, and higher education. The infrastructure development index has increased significantly over the past decade. Technology readiness and market size also contribute positively. The regression result between GDP and GCI as presented in Table 3: GCI $=0.647 \mathrm{LnGDP}$ has shown a positive and significant effect $(\alpha=0.10)$, and GDP can be a predictor for GCI in Vietnam.

Table 3 also presents the regression result of the influence of GDP on GCI of ASEAN-7 overall. For the ASEAN-7 group, the regression result is $\mathrm{GCI}_{\mathrm{ASEAN}-7}=0.519 \mathrm{LnGDP}$. The GDP of ASEAN-7 GDP has a positive and significant effect $(\alpha=0.01)$ on GCI. This means that during the period of 2008-2009 to 2016-2017, an increase of $1 \%$ (US \$ 19.21 billion) in the GDP of ASEAN-7 will be able to raise GCI by 0.519 points. The regression result for each ASEAN-7 countries shows that Philippine is the most efficient to use its GDP to increase the GCI. It is then followed by Singapore, Indonesia, Cambodia, Malaysia, and Vietnam. While Thailand is considered to be less able to optimize its GDP to increase GCI. The relationship between GCI and GDP in ASEAN-7 countries is also strengthened by other studies. For example, the study of Xia et al. (2012) shows that GCI can be used as a good standard for measuring economic growth. Rota (2013) also stated that GCI has a positive and significant relationship with GDP per capita. Therefore, for ASEAN-7, GDP is a very good predictor of global competition.

\section{Inhibiting Factors in Improving GCI}

According to the WEF Report year of 2016-2017, there are 16 factors that can hinder the increase of GCI or often also called the most problematic factors in doing business. These factors are what business executives see as the most problematic in doing business in their economy. This information is taken from the survey of WEF's Executive opinion every year. Usually, out of these 16 factors, business executive respondents are asked to choose the five most problematic and give peering from 1 (most problematic) to 5 . Then the results are tabulated and given intensity weight according to the ratings given by the respondent. The 16 factors are: Access to financing, Inefficient government bureaucracy, Poor work ethic in national labor force, Inadequate supply of infrastructure, Corruption, Tax rates, Inadequately educated workforce, Policy instability, Crime and theft, Inflation, Tax regulations, Insufficient capacity to innovate, Foreign currency regulations, Government instability, Poor public health, Restrictive labor regulations.

After reviewing the 16 factors, in general, it is found that ASEAN-7 countries have five most problematic factors in year of 2016-2017, namely: corruption, inadequately educated workforce, access to financing, taxes regulations, and inefficient government bureaucracy. The five most problematic factors in doing business in each country vary greatly in the intensity value. The corruption is still included in the five most problematic factors in doing business in 5 countries, namely Philippine, Indonesia, Malaysia, Cambodia, and Thailand, but the intensity is different. 
For Singapore and Vietnam, corruption is no longer the most problematic factor in running a business. The highest intensity of corruption is in Cambodia and Thailand, then Philippine, Indonesia, and Malaysia. Even corruption is the main problem in Thailand, Cambodia, and Indonesia.

For Philippine, in 2016-2017, the main problem in doing business is an inefficient government bureaucracy. In Indonesia and Cambodia, in 2016-2017, corruption remains a major problem in doing business. In Malaysia, the main problem is access to financing. The restrictive labour regulations are a major problem in conducting business in Singapore. The intensity of corruption is increasing in Thailand and is a major problem in running a business while the availability of an educated workforce is a major problem in the country of Vietnam.

Raimanu (2016) states that the economic condition of a country is one of the important factors considered by multinational companies when they are going to make business decisions. Therefore, factors inhibiting business competitiveness will affect a country's economic conditions. Economic conditions will affect changes in currency values, economic growth, inflation, interest rates which will ultimately affect the operations of multinational companies that do business in a country.

\section{Conclusion and Suggestion}

\section{Conclusion}

During the period of 2008-2009 to 2016-2017 the global competitiveness index of each ASEAN7 countries continues to increase, except Cambodia, whereas during the period, at the world level, the competitiveness ranking of each ASEAN-7 countries continues to increase, except for Malaysia and Cambodia. Philippine, Indonesia, and Vietnam have shown a very significant increase in competitiveness. The pillars of the basic requirements sub-index still dominate the biggest contribution to the increase of the competitiveness index for the country of Indonesia, Philippine, Thailand, Cambodia, and Vietnam. As for Malaysia and Singapore, the efficiency enhancers and innovation-sophistication sub-index have been able to provide the greatest contribution to the increase in the global competitiveness index.

The estimation result shows that ASEAN-7 countries' GDP has a positive and significant effect on increasing the GCI, except for Thailand. The most problematic factors in running a business are corruption, inadequately educated workforce, access to financing, taxes regulations, and inefficient government bureaucracy.

\section{Suggestion}

To improve the global competitiveness index, ASEAN-7 countries need to make improvements for the sub-index and competitiveness pillars by adjusting the categories of development stages. ASEAN-7 countries are expected to continue to boost their GDP because increasing GDP is a good predictor of the GCI. To complete the ranking of the progress of each country compared to other countries, it is necessary to analyze other indices such as the Corruption Perception Index (Transparency International), the Doing Business Indicator (World Bank), the Human Development Index (UNDP), and The Climate Competitiveness Index (UN). 
IJBE (Integrated Journal of Business and Economics)

e-ISSN: 2549-3280/p-ISSN: 2549-5933

I also encourage the readers to further refine the GCI index by including other variables such as entrepreneurship and the component of national culture in the index so that it can become more numerous reliable indexes. In addition, it might be better to predict economic growth in the future.

\section{References}

1) Bai, S. (2009). Measuring Financial Integration in the BRIC Nations. International Journal of Services and Standards, 5(3). p. 257-275, DOI: http://dx.doi.org/10.1504/IJSS.2009.028676.

2) Bank Indonesia (2016). Meta Data of Gross Domestic Product (GDP), Departemen Statistik Bank Indonesia, Jakarta. URL: http://www.bi.go.id/id/statistik/metadata/seki/Documents/14.\%20PDB.

3) Hutabarat, B. F. (2014). "Strengthening Agricultural Product Competitiveness: Improving Indonesia's Agricultural Development Performance Is Not Simply Based on Competitiveness" (Memperkuat Daya Saing Produk Pertanian: Peningkatan Kinerja Pembangunan Pertanian Indonesia Tidak Semata-mata Bertumpu Pada Daya Saing), URL: http://www. Litbang · pertanian. go.id/buku/ memperkuat_dayasaing_produk_pe/BAB-II-1.pdf.

4) IDABC Government Observatory. (2005). The Impact of e-Government on Competitiveness, Growth and Jobs. URL: http://www.cisco.com/c/dam/global/de_de/assets/pdfs.

5) Koong, K. S., Flores, J., Sun, J., \& Liu, L. C. (2011). Health Information Technology Performance Measures: a Lifecycle Analysis. International Journal of Services and Standards, 7(3/4), p. 181-196, DOI: http://dx.doi.org/10.1504/IJSS.2011.045048.

6) Kordalska, A. \& Olczyk, M. (2016). Global Competitiveness and Economic Growth: A One-Way or Two-Way Relationship?. Equilibrium. Quarterly Journal of Economics and Economic Policy, 11(1), p. 121-142. DOI: http://dx.doi.org/10.12775/ EQUIL.2016.006

7) Lopez-Claros, A., Altinger, L., Blanke, J., Drzeniek, M., \& Mia, I. (2006). The Global Competitiveness Index: Identifying the Key Elements of Sustainable Growth. The Global Competitiveness Report 2006-2007. World Economic Forum, Palgrave Macmillan.

8) Mankiw, N. G. (2007). Macroeconomics, Edisi Keenam. Erlangga.Jakarta.

9) Martin, R. L. (2004). A Study on the Factors of Regional Competitiveness. A draft final report for the European Commission, Directorate-General Regional Policy, Cambridge Econometrics.URL: http://ec.europa.eu/regional_policy/sources/docgener/studies/pdf/3cr/competitiveness.

10) McArthur, J. W. and Sachs, J. D. (2002). 'The growth competitiveness index: measuring technological advancement and the stages of development', in Porter, M.E., Sachs, J.D.

11) Cornelius, P. K., McArthur, J. W., and Schwab, K. (Eds): The Global Competitiveness Report 20012002, Oxford University Press, New York, pp.28-51.

12) Monga, C. \& Lin., T.Y. (2015). The Oxford Handbooks of Africa and Economics, Volume I: Context and Concept, Oxford University Press, UK. URL: https://books.google. co.id/ books ?id= Economy 1992.

13) Nababan, T. S. (2014). "Building A Sustainable Entrepreneurship In Increasing Global Competitiveness" (Membangun Sustainable Entrepreneurship Untuk Meningkatkan Daya Saing Global, Proceeding "National Seminar \& Call for Paper "The Impact of ASEAN Economic Community 2015: Opportunities \& Benefits for Indonesians Entrepreneurs", Faculty of Economics, Maranatha Christian University, held on $22-24$ May 2014, Bandung. URL: https://papers.ssrn.com/sol3/papers.cfm?abstract_id=2633882. 
14) Qin, H., Prybutok, V. R., \& Peak, D. A. (2009). Service Quality in the USA and Mainland China's Fast-food restaurants. International Journal of Services and Standards, 5(4). p 291-315, DOI: http://dx.doi.org/10.1504/IJSS.2009.032174.

15) Raimanu, G. (2016). “Analysis of Indonesia's Competitiveness 2016-2017: An Analysis of International Financial Management Policy” (Analisis Daya Saing Indonesia Tahun 2016-2017: Sebuah Analisis Kebijakan Manajemen Keuangan Internasional), Tadulako University, URL: https: // www.researchgate.net/publication/311594011.

16) Rota, L. (2013). An assessment of the relationship between Global Competitiveness Index Scores and National GDP per capita growth rates. Gordon Institute of Business Science, University of Pretoria. URL: http://repository.up.ac.za/xmlui/bitstream/handle/2263/40642/Rota Assessment 2013.pdf ?.

17) Sukirno, S. (2010). Introduction to Macroeconomics Theory (Teori Pengantar Makroekonomi), Edisi Ketiga. Raja Grafindo. Jakarta.

18) Schwab, K. (2015). The Global Competitiveness Report 2014-2015. URL: http://www.weforum.org.

19) Tambunan, T. (2011). "Indonesia's Global Competitiveness" (Daya Saing Global Indonesia): World Economic Forum 2010-2011", Center for Industry, SME and Business, in Advancing Indonesia's Civil Society in Trade and Investment Climate (ACTIVE) Programmed, KADIN Indonesia.

20) Tan, K. G. \& Tan, K. Y. (2014). Assessing competitiveness of ASEAN-10 Economies, International Journal of Economics and Business Research, Vol. 8, No. 4, 2014, pp. 377-398.

21) Xia, R., Liang,T., Zhang,Y., \& Wu, S. (2012). Is Global Competitive Index A Good Standard to Measure Economic Growth? A Suggestion For Improvement, International Journal of Services and Standards, Vol. 8, No. 1, 2012, pp. 45-57. URL: https://www.researchgate.net /publication/235499154. WEF (World Economic Forum), The Global Competitiveness Report, The period of year 2008-2009 to 2016-2017. URL: https://www.weforum.org/.../world-economic-forumannual. 